\title{
Performance of crisphead lettuce cultivars under protected environment in different times of production ${ }^{1}$
}

\author{
Eduardo Santana Aires ${ }^{2 *}$ (D), Carlos Alberto Aragão ${ }^{3}$, Lígia Borges Marinho ${ }^{3}$ Ítala Laiane Silva Gomes ${ }^{3}$, \\ Antônio Bruno Nunes Oliveira ${ }^{3}$, Jony Eishi Yuri ${ }^{4}$
}

$10.1590 / 0034-737 X 202067040003$

\begin{abstract}
The objective of this work was to evaluate the behavior of Crisphead lettuce as a function of production seasons under different forms of protected environment. Two experiments were carried out in the field at different times: September to December 2017 and June to August 2018, in a randomizaed blocks desing, in a 4 x 7 factorial scheme, the first one being production environments under shade nets: red screen, chromatinet ${ }^{\circledR}$ screen, black screen and full sun, and the second, lettuce cultivars: Winslow, Irene, Balsamo, Rafaela, Iron Wood, Great Lakes and Delícia. The harvest was carried out at forty-two days after transplanting, where the following variables were analyzed: stem length $(\mathrm{cm})$, total production and commercial productivity $\left(\right.$ t.ha $\left.\mathrm{a}^{-1}\right)$. The data were submitted to analysis of variance, and a joint analysis was performed to analyze the treatments effect, then the means were compared by the Scott-Knott test, at 5\% probability. The microclimate was altered in the shaded beds, which affected the cultivars development. The cultivation in protected environment provides higher productivity of Crisphead lettuce from September to December, at that time the cultivars Balsamo and Delicia were highlighted under chromatinet ${ }^{\circledR}$. In the period of mild temperatures, a better performance was observed for cv. Balsamo in full sun.
\end{abstract}

Keywords: Lactuca sativa var. capitata; handling; screens shading

\section{INTRODUCTION}

In the segment of leafy vegetables, the most produced is lettuce (Lactuca sativa L.). This represented around $50 \%$ of Brazil's production and sales in 2018 (HF, 2019). In the year 2017, approximately $49,436 \mathrm{t}$ of lettuce were commercialized in CEAGESP, with the main group being the Crisphead type, with $47 \%$ of the total commercialization. (CEAGESP, 2018). The cultivation of this vegetable generates income, mainly for small and medium producers, and it drives a high volume of resources such as seeds, fertilizers, pesticides and labor.

The majority of Crisphead lettuce is commercialized in the warehouse of São Paulo, due to the proximity of the major producing regions: Minas Gerais, Rio de Janeiro and São Paulo. While Ceasas of Ceará and Pernambuco were responsible for about 750 tons, less than $15 \%$ of the Brazilian market (CONAB, 2018).

This is because the production of Crisphead lettuce (Lactuca sativa var. capitata), is disadvantageous in regions with high temperatures. When these, exceed $20^{\circ} \mathrm{C}$, plant bolting is induced early, causing depreciation of the final product (Santi et al., 2010). Thus, production data of this vegetable in regions with high temperatures in most of the year, such as the Brazilian semi-arid, are incipient. The sub-region of the São Francisco Valley has agricultural areas and access to water that makes irrigation possible, so it is efficient for the production of quality vegetables and high productivity. In addition to being close to the largest distribution centers in the Brazilian Northeast, facilitating

\footnotetext{
Submitted on August $01^{s t}, 2019$ and accepted on July $20^{\text {th }}, 2020$.

${ }^{1}$ This work is part of the master's dissertation of the first author.

${ }^{2}$ Universidade Estadual Paulista, Departamento de Horticultura, Botucatu, São Paulo, Brazil. e.aires@unesp.br

${ }^{3}$ Universidade do Estado da Bahia, Departamento de Tecnologia e Ciências Sociais, Juazeiro, Bahia, Brazil. caaragao@uneb.br; lbmarinho@uneb.br; ítala.gomes@hotmail.com; bruno.xcv@outlook.com

${ }^{4}$ Empresa Brasileira de Pesquisa Agropecuária, EMBRAPA Semiárido, Petrolina, Pernambuco, Brazil. jony.yuri@embrapa.br

*Corresponding author: e.aires@unesp.br
} 
the commercialization. However, some agroclimatic factors can delay or hinder the development of crops, such as average air temperature and high solar radiation.

The use of shading screens has great advantages, including positive responses in plant physiological processes, as well as yield and product quality (Iliæ et al., 2017). It may also reduce the direct incidence of solar radiation, especially in leafy vegetable, such as lettuce; which can attenuate the deleterious effects of high temperature in the leaves. Leafy vegetable, as lettuce, cultivation under shade screens has been studied (Ferreira et al., 2014; Paula et al., 2015). Reporting, increments of up to 10 t.ha $^{-1}$, when the thermo-reflective screen is compared with the full sun, under tropical conditions (Neves et al., 2016). Therefore, the production in protected environment can allow better performance of the Crisphead lettuce under conditions limiting its development, when compared to the crop in full sun.

Another important aspect of the Crisphead lettuce production system is the growing season of this vegetable. Primarily in regions with an intra-annual climatic variability, such as Submedia region of the São Francisco Valley. Therefore, studies should recommend cultivars that can produce satisfactorily throughout the year or specific genotypes to each climate condition during the year.

Identification of Crisphead lettuce cultivars with good performance in field or in a greenhouse environment under high temperature conditions, will allow planting in times of low supply, increasing competitiveness of this region when compared to other producers. Selection and development of cultivars and lettuce cultivation techniques appropriate to these areas will also reduce crop loss and improve economic opportunity for producers, especially family farmers.

Therefore, the objective of this work was to evaluate the production of crisphead lettuce cultivars in two growing seasons, under different semi-protected environments, in the Submedia of the São Francisco Valley.

\section{MATERIAL AND METHODS}

The experiments were conducted in the experimental area of vegetables of the State University of Bahia - UNEB, located in the city of Juazeiro-BA. The region has an average elevation of $360 \mathrm{~m}$ at sea level, latitude $9^{\circ} 25^{\prime} 14^{\prime \prime} \mathrm{S}$ and longitude $40^{\circ} 29^{\prime} 08^{\prime \prime} \mathrm{W}$. According to the Köppen classification, the region presents a semi-arid BSWh type climate, with a mean temperature and precipitation of 23.6 ${ }^{\circ} \mathrm{C}$ and $455 \mathrm{~mm}$, respectively.

The experimental design was a randomized block design in a $7 \times 4$ factorial scheme, with seven Crisphead lettuce cultivars (Winslow, Irene, Balsamo, Rafaela, Iron Wood, Great Lakes and Delícia) and four environments:
Red screen (RS), chromatinet $^{\circledR}$ (CS), black (BS) and full sun (FS), with three replicates. Each plot was composed of twelve plants, and the four plants were evaluated as useful plots. Most of the cultivars studied are indicated for summer or year-round cultivation, except cvs. Balsamo and Rafaela that are indicated for winter cultivation.

The experiments were conducted in two areas, the first comprised the period from September to December 2017 (high average temperatures), while the second was from June to August 2018 (mild average temperatures). The lettuce seedlings were prepared in expanded polystyrene trays filled with commercial Plantmax ${ }^{\circledR}$ substrate, with a 4.90 g.kg ${ }^{-1}$ of $\mathrm{N}, 1.47 \mathrm{~g} . \mathrm{kg}^{-1}$ of $\mathrm{P}, 7.0 \mathrm{~g} \cdot \mathrm{kg}^{-1} \mathrm{~K}, 12.50 \mathrm{~g} \cdot \mathrm{kg}^{-1}$ of $\mathrm{Ca}, 120 \mathrm{~g} . \mathrm{kg}^{-1}$ of $\mathrm{Mg}, 1.80 \mathrm{~g} \cdot \mathrm{kg}^{-1}$ of $\mathrm{S}, \mathrm{C} / \mathrm{N}$ of $34 / 1$,

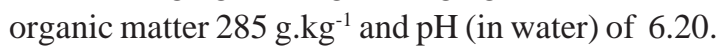

The trays were placed on benches with $0.5 \mathrm{~m}$ height, under protected environment covered with $50 \%$ black shading screen. Transplanting took place twenty-five days after sowing (DAS), in four rows with spacing of $0.25 \times 0.25 \mathrm{~m}$.

The area soil was classified as Entisols (Santos et al., 2018) and the $0-20 \mathrm{~cm}$ layer had the following chemical characteristics: $\mathrm{pH}\left(\mathrm{H}_{2} 0\right)=6.42 ; \mathrm{P}=56 \mathrm{mg} \mathrm{dm}^{-3} ; \mathrm{K}=0.22$ $\mathrm{cmol}_{\mathrm{c}} \mathrm{dm}^{-3} ; \mathrm{Ca}=5.0 \mathrm{cmolc} \mathrm{dm}^{-3} ; \mathrm{Mg}=1.70 \mathrm{cmol}_{\mathrm{c}} \mathrm{dm}^{-3} ; \mathrm{Al}=$ $0.0 \mathrm{cmol}_{\mathrm{c}} \mathrm{dm}^{-3} ; \mathrm{CCS}=7.01 \mathrm{cmol}_{\mathrm{c}} \mathrm{dm}^{-3} ; \mathrm{CE}_{\mathrm{es}}=0.77 \mathrm{dS} . \mathrm{m}^{-1}$.

Soil preparation was performed with plowing, harrowing and lifting of the beds at $30 \mathrm{~cm}$ height, each plot was 28 meters long by $1.5 \mathrm{~m}$ wide, each experimental plot was $0.75 \times 1.50 \mathrm{~m}$ with twelve plants. The environments had a right foot of $2.00 \mathrm{~m}$ and the screens were fixed in eucalyptus stakes with wire at a height of $1.50 \mathrm{~m}$.

Planting fertilization was based on the state of Bahia fertilization recommendation for lettuce cultivation, and according to the soil analysis $6.3 \mathrm{~kg} \cdot \mathrm{ha}^{-1}$ of $\mathrm{N}$ and $21,3 \mathrm{~kg}$ of $\mathrm{P}_{2} \mathrm{O}_{5} \mathrm{ha}^{-1}$ as source, urea $(44 \% \mathrm{~N})$ and single superphosphate $\left(18 \%\right.$ de $\left.\mathrm{P}_{2} \mathrm{O}_{5}\right)$ were used. Coverage was applied 20 days after transplanting, adding $38.0 \mathrm{~kg} \cdot \mathrm{ha}^{-1}$ of $\mathrm{N}$ and $26.0 \mathrm{~kg} \cdot \mathrm{ha}^{-1}$ of Ca using as the source calcium nitrate ( $15 \% \mathrm{~N}$ and $19 \%$ of $\mathrm{Ca})$.

For irrigation management, three tensiometers were used per plot. Samples were collected in the $0-20 \mathrm{~cm}$ soil layer of the beds for physical-water characterization, and with this result the water retention curve in the soil was made. From this, the matric potential values were converted to gravimetric humidity. The irrigation level applied at each irrigation was determined based on the matric potentials using the means of the tensiometer readings. Which were installed per environment at $10 \mathrm{~cm}$ depth representing the 0-20 cm layer. The irrigation level was applied through a micro-sprinkler system, with a flow emitter of $10 \mathrm{~L} \mathrm{~h}^{-1}$, spaced every $1.0 \mathrm{~m}$. For phytosanitary and weed control, the treatments commonly applied in the crop were used, according to Yuri et al. (2017). 
In the crop environments with black, red and chromatinet $^{\circledR}$ shading screens the meteorological elements were monitored by means of meteorological sensors installed at $50 \mathrm{~cm}$ high, they were connected to an automatic data system (Datalogger), programmed to carry out readings to each five seconds and hourly averages. The meteorological elements monitored in each environment were: air temperature (average, maximum and minimum); relative humidity (mean, maximum and minimum); and solar radiation. The sensors were installed in each environment for five days, so it was possible to correlate the data between the shaded and open environments, in which there was an automatic meteorological station, $300 \mathrm{~m}$ away from the experimental area.

Harvesting was carried out at 45 days after transplanting (DAT), and the length of the stem $(\mathrm{cm})$ was evaluated after cutting the head of the lettuce in half. The total fresh mass (g.plant ${ }^{-1}$ ) was obtained by cutting the plants close to the ground and weighing in a digital scale, while the commercial fresh mass (g.plant ${ }^{-1}$ ) was obtained by weighing only the head, removing the outer sheets. With the results of the total and commercial fresh mass, the extrapolation was carried out to calculate the total production and commercial productivity $\left(\mathrm{t} \cdot \mathrm{ha}^{-1}\right)$.

The collected data were submitted to analysis of variance, for each experiment, and after observing the minimum variation between the largest and the smallest mean square of the residue, a joint variance analysis was performed to verify the isolated or combined effects of the evaluated factors: cultivars, environments and times of production. Then, using the F-test for comparison of the $5 \%$ average squares, the means were compared by the Scott-Knott test, at $5 \%$ probability.

\section{RESULTS AND DISCUSION}

The microclimatic conditions were altered by the use of shading screens, such as by the time of year of production, especially in the second semester (September to December) when compared to full sun. The meteorological variations are preponderant in the viability of the cultivation of vegetables and, in the case of Crisphead lettuce, temperature and solar radiation are the most important variables. The average temperature data at different times and in the different shaded environments are shown in Figure 1. It is generally observed that in the first cycle, from September to December 2017, the average was around $30{ }^{\circ} \mathrm{C}$. While in the second, from June to August 2018 , this value was $25^{\circ} \mathrm{C}$.

In both planting seasons, the use of black and chromatinet ${ }^{\circledR}$ shading screens caused a slight reduction in the average air temperature in the beds, of about $0.5^{\circ} \mathrm{C}$.
In general terms, the agroclimatic results corroborate with Gama et al. (2017), who working with shade screens for the production of cherry tomatoes in the same region of the present research, identified microclimatic changes in the environments, however, with greater changes for solar radiation, whereas, the average temperature did not vary in any way significant.

For the Petrolina-Juazeiro dipole region, the hottest months are October and November, and the coldest months are June and July (Heriberto \& Teixeira, 2010). In addition to higher temperatures, solar radiation is also more intense in the period from October to December (Figure 2a). At the same time, the red, chromatinet ${ }^{\circledR}$ and black shading screens reduced direct sunlight by 20,40 and $45 \%$, respectively.

Regarding the microclimatic evaluated characteristics, a larger difference is observed between the values of global solar radiation, for the two production seasons. This has direct action on photosynthesis and, in transpiration; shaded plants tend to narrow the thickness of the leaves, thus accelerating the photosynthetic process. While plants exposed to full sun, they may lose productivity due to increased evapotranspiratory demand.

According to Jie \& Kong (1998), in experiments with lettuce, global solar radiation around $20.7 \mathrm{MJ} \mathrm{m}^{-2}$ favors maximum photosynthetic rate of the crop. Although screens promoted a reduction in radiation, for the first production period (September to December), shading generated by the black and chromatinet ${ }^{\circledR}$ was around 19.5 $\mathrm{MJ} \mathrm{m}^{-2}$, thus justifying highest productions of Crisphead lettuce when compared to full sun, which presented about $30 \mathrm{MJ} \mathrm{m}^{-2}$ on average during the cycle.

However, for the second season (June to August), shading screens promoted an attenuation that reduced overall solar radiation to approximately $10 \mathrm{MJ} \mathrm{m}^{-2}$, half of the value described as optimal for photosynthesis. While the full sun presented about $20 \mathrm{MJ} \mathrm{m}^{-2}$, promoting better performance for the cultivars studied in this environment at that time.

In addition, protected-environment cultivation provides a reduction in water requirements and makes plant water use more efficient due to reduced evapotranspiration (Oliveira et al., 2014). The main meteorological factor for the composition of reference evapotranspiration, in shaded and open sky environments, is solar radiation. In the present research it is noticed that Crisphead lettuce, in the second semester (September to December), presented higher production in the shaded environments with chromatinet ${ }^{\circledR}$ and black screen, when compared to full sun. This may be due to improved water use efficiency and high radiation observed during the cultivation of Crisphead lettuces. Being that cultivation in full sun influenced the closure of the stomata 
and sweating interruption. Santiago et al. (2018), observed microclimatic and productive differences of cherry tomato under protected conditions in the region of Juazeiro-BA; associating the low productivity of the plants conducted in full sun to the high atmospheric demand. Which is characterized mainly by high incidence of solar radiation and low air humidity, since a high rate of evaporation, consequently reducing available water content and nutrients absorption.

In this way, the production of cultivars was altered by the effects of shading screens under beds and for periods that the work was conducted. For cultivation and commercialization of Crisphead lettuce, stem length should be analyzed to measure the compactness of the head, which is the commercial product. More compact heads are intended for industrial processing, while less compacted or longer stem lengths are intended for "in natura" consumption. Length of stem up to $6.0 \mathrm{~cm}$ are most suitable and acceptable up to the $9.0 \mathrm{~cm}$ level and unacceptable or less recommended for processing above this. (Yuri et al., 2004; Resende et al., 2005).
The length of the lettuce stem varied significantly (p $<0.05)$ as a cultivar function, time of production and environment used for cultivation (Table 1). The use of shading screens in lettuce cultivation promoted an increase in length of the lettuce stem. Cultivars under effect of chromatinet ${ }^{\circledR}$ screen had a significant effect as a function of production time ( $\mathrm{p}<0.05)$.

While in cultivation from June to August/2018, all the cultivars presented diminutive stem, except cv. Great Lakes under chromatinet ${ }^{\circledast}$ fabric and in this environment, the cultivars Irene, Balsamo, Rafaela and Delícia decreased the stem length. According to Aquino et al. (2017), this indicates higher resistance of these cultivars to early tillage. No increase in lettuce stem length was observed using shade screens when cultivated from June to August/ 2018. This difference can be related to the decrease in the mean air temperature (Figure 1) of this time, when compared to the period from September to December/2017.

Cultivars showed a decrease of the stem when exposed to full sun, observing that use of shading screens promoted an increase in stem length, only in
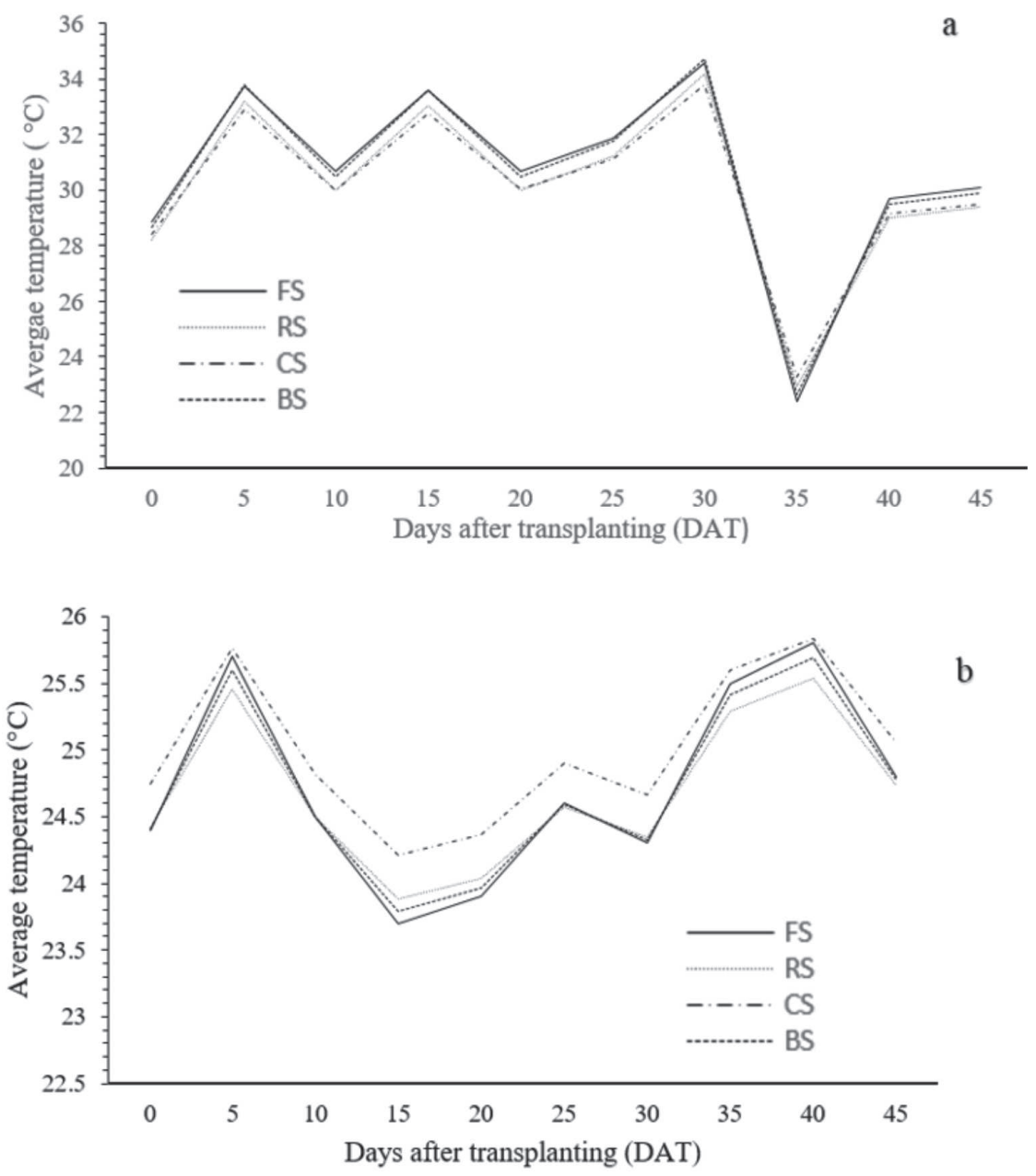

Figure 1: Average air temperature $\left({ }^{\circ} \mathrm{C}\right)$ in full sun $(\mathrm{FS})$ and in shaded environments with red screen $(\mathrm{RS})$, chromatinet ${ }^{\circledR}(\mathrm{CS})$ and black (BS). In the periods from September to December (a) and from June to August (b). 
the production season from September to December/ 2017, for most of cultivars of Crisphead lettuce used, except for Irene and Winslow. The microclimatic conditions generated by crop protection can directly affect their growth and development (Hassanien \& Li, 2017). Based on this principle, it is possible that lettuce plants under full sun have kept the stomata closed for long periods during the day, stagnating the photosynthesis and consequently limiting its development.

Another important aspect is the low light-saturation point of the lettuce plants (Stagnari et al., 2015), under conditions of high solar radiation, as observed in the period from September to December, the rate of net photosynthesis of the plant is reduced causing less growth. Physiologically, under shading nets, there may also be an increase in the levels of chlorophyll $a$ and $b$ and carotenoids, when compared to plants grown in full sun, as reported by Iliæ et al. (2019) in lettuce plants, this happens because in plants submitted to high solar radiation, chlorophyll degradation occurs.
Therefore, for the studied crisphead lettuce cultivars, solar radiation above $20 \mathrm{MJ} . \mathrm{m}^{-2}$ can cause chlorophyll degradation and reduce the net photosynthesis of plants, negatively affecting production. For plants grown under chromatinet $^{\circledR}$ and black screens, in September-December, the chlorophyll content may have been enough to absorb more light energy, which allowed the plants to achieve greater $\mathrm{CO}_{2}$ assimilation, and consequently greater productivity.

For total production (Table 2) there were significant differences for cultivars, environments and production time. The combination was highlighted: cv. Balsamo, full sun and period from June to August/2018, with approximately 74.0 t.ha $^{-1}$. Yuri et al. (2017), evaluating the performance of crisphead lettuce genotypes in the same region of the present research, found total productivity of cv. Balsamo of $72.8 \mathrm{t}^{\text {tha }}{ }^{-1}$, from May to July, in open field. Thus, it is verified that this cultivar can be indicated for cultivation in the Submedia region of the São Francisco Valley in times of mild temperatures, without use of shading screens.
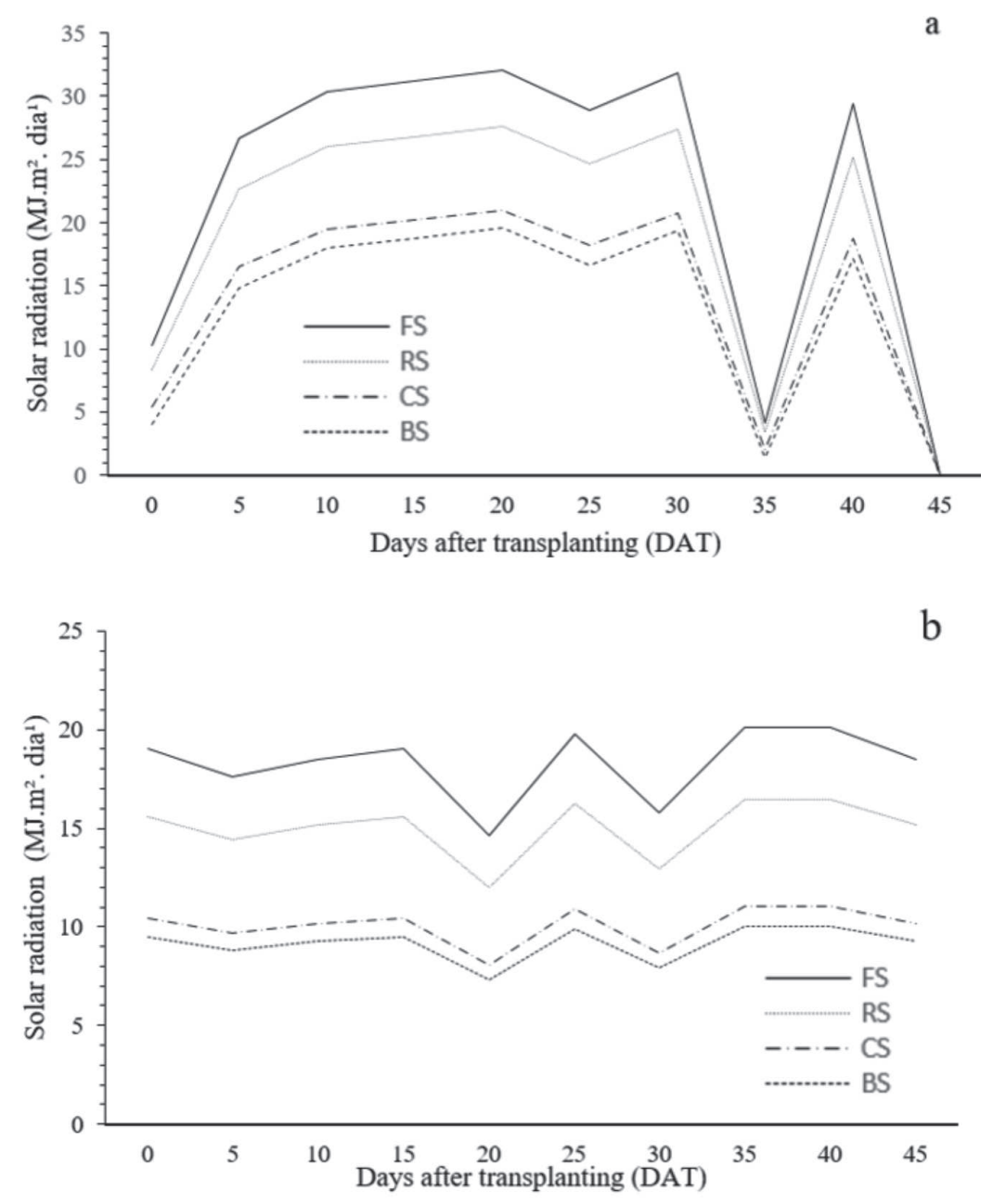

Figure 2: Global solar radiation ( $\left.\mathrm{MJ} \mathrm{m}^{-2} \mathrm{day}^{1}\right)$ in full sun (FS) and in shaded environments with red screen (RS), chromatinet $^{\circledR}(\mathrm{CS})$ and black (BS). In the periods from September to December (a) and from June to August (b). 


\begin{tabular}{|c|c|c|c|c|c|c|c|c|}
\hline \multirow{3}{*}{ Cultivars } & \multicolumn{4}{|c|}{ Period: Sep - Dec 2017} & \multicolumn{4}{|c|}{ Period: Jun - Aug 2018} \\
\hline & \multicolumn{4}{|c|}{ mbient } & \multicolumn{4}{|c|}{ Ambient } \\
\hline & RS & $\mathrm{CS}$ & BS & FS & RS & $\mathrm{CS}$ & BS & FS \\
\hline Winslow & $8.31 \mathrm{Ba} a$ & $6.20 \mathrm{Ba} a$ & $6.86 \mathrm{Aa} a$ & 5.45 Аа $a$ & $3.91 \mathrm{Ba} a$ & $4.25 \mathrm{Ba} a$ & 3.88 Аа $a$ & 5.75 Аа $a$ \\
\hline Irene & $7.28 \mathrm{Ba} a$ & $7.35 \mathrm{Ba} a$ & $6.90 \mathrm{Aa} a$ & 5.70 Аа $a$ & $4.83 \mathrm{Ba} a$ & $4.62 \mathrm{Ba} b$ & 4.58 Аа $a$ & $5.25 \mathrm{Ab} a$ \\
\hline Balsamo & $8.71 \mathrm{Ba} a$ & $6.86 \mathrm{Bb} a$ & $5.65 \mathrm{Ab} a$ & $5.42 \mathrm{Ab} a$ & $5.87 \mathrm{Aa} a$ & $4.16 \mathrm{Ba} b$ & $3.58 \mathrm{Aa} a$ & 5.87 Аа $a$ \\
\hline Rafaela & 11.7 Аа $a$ & 10.3 Аа $a$ & $9.23 \mathrm{Aa} a$ & $6.31 \mathrm{Ab} a$ & $6.83 \mathrm{Aa} a$ & $5.18 \mathrm{Ba} b$ & 4.75 Аа $a$ & $5.58 \mathrm{Aa} a$ \\
\hline Iron Wood & $8.35 \mathrm{Ba} a$ & $5.98 \mathrm{Ba} a$ & $6.41 \mathrm{Aa} a$ & $3.10 \mathrm{Ab} a$ & $4.75 \mathrm{Ba} a$ & $6.25 \mathrm{Ba} a$ & 5.08 Аа $a$ & $4.66 \mathrm{Ba} a$ \\
\hline Great Lakes & $7.66 \mathrm{Ba} a$ & $7.06 \mathrm{Ba} b$ & $7.60 \mathrm{Aa} a$ & $4.71 \mathrm{Ab} a$ & $5.30 \mathrm{Bc} a$ & 9.75 Аа $a$ & 4.21 Ac $a$ & $6.83 \mathrm{Ab} a$ \\
\hline Delícia & 10.6 Аa $a$ & $6.45 \mathrm{Bb} a$ & $6.06 \mathrm{Ab} a$ & $4.72 \mathrm{Ab} a$ & $4.25 \mathrm{Ba} a$ & $3.41 \mathrm{Ba} b$ & 4.21 Aa $a$ & $3.83 \mathrm{Ba} a$ \\
\hline
\end{tabular}

RS- Red Screen; CS- Chromatinet ${ }^{\oplus}$ Screen; BS- Black Screen and FS- Full Sun. Averages followed by different letters, upper case in columns, differ between cultivars; lowercase in lines, between environments; and italics, between the production times for the same cultivar and the same environments, by the Scott \& Knott test, at $5 \%$ probability.

Table 2: Average values for total production of Crisphead lettuce cultivars under protected environment in two production seasons, in the Submedia of the São Francisco Valley. Juazeiro-BA (2019)

\begin{tabular}{|c|c|c|c|c|c|c|c|c|}
\hline \multicolumn{9}{|c|}{ Total production (t ha' $\left.\mathbf{h}^{-1}\right)$} \\
\hline \multirow{3}{*}{ Cultivars } & \multicolumn{4}{|c|}{ Period: Sep - Dec 2017} & \multicolumn{4}{|c|}{ Period: Jun - Aug 2018} \\
\hline & \multicolumn{4}{|c|}{ Ambient } & \multicolumn{4}{|c|}{ Ambient } \\
\hline & $\mathbf{R S}$ & $\mathrm{CS}$ & BS & FS & $\mathbf{R S}$ & $\mathrm{CS}$ & BS & FS \\
\hline Winslow & 55.52 Аа $a$ & $42.24 \mathrm{Cc} b$ & $46.02 \mathrm{Ab} a$ & $32.64 \operatorname{Ad} b$ & $33.10 \mathrm{Bb} b$ & $53.15 \mathrm{Aa} a$ & $32.80 \mathrm{Bb} a$ & $53.82 \mathrm{Ba} a$ \\
\hline Irene & $29.12 \mathrm{Cb} b$ & $50.64 \mathrm{Ba} b$ & 45.44 Аа $a$ & $25.68 \mathrm{Bb} b$ & $44.05 \mathrm{Bb} a$ & $58.85 \mathrm{Aa} a$ & $52.48 \mathrm{Ab} a$ & $62.11 \mathrm{Ba} a$ \\
\hline Balsamo & $55.14 \mathrm{Ab} a$ & 65.52 Аа $a$ & $52.80 \mathrm{Ab} a$ & $34.34 \mathrm{Ac} b$ & $54.16 \mathrm{Ab} a$ & $47.98 \mathrm{Ab} b$ & $55.70 \mathrm{Ab} a$ & 73.35 Аа $a$ \\
\hline Rafaela & $40.21 \mathrm{Bb} b$ & $55.20 \mathrm{Ba} a$ & 47.62 Аа $a$ & $22.08 \mathrm{Bc} b$ & $48.21 \mathrm{Aa} a$ & $53.81 \mathrm{Aa} a$ & $54.27 \mathrm{Aa} a$ & $56.66 \mathrm{Ba} a$ \\
\hline Iron Wood & 51.12 Aa $a$ & $42.08 \mathrm{Ca} b$ & 47.68 Аа $a$ & $28.48 \mathrm{Ac} b$ & $52.86 \mathrm{Aa} a$ & $63.61 \mathrm{Aa} a$ & $41.90 \mathrm{Bb} a$ & $55.11 \mathrm{Ba} a$ \\
\hline Great Lakes & $38.16 \mathrm{Bb} b$ & $33.44 \mathrm{Db} b$ & 50.40 Аа $a$ & $20.64 \mathrm{Bc} b$ & $52.26 \mathrm{Aa} a$ & $57.71 \mathrm{Aa} a$ & $52.50 \mathrm{Aa} a$ & $48.95 \mathrm{Ca} a$ \\
\hline Delícia & $44.64 \mathrm{Ba} b$ & $49.22 \mathrm{Ba} a$ & 43.62 Аа $a$ & $28.64 \mathrm{Ab} b$ & $53.15 \mathrm{Aa} a$ & $44.35 \mathrm{Aa} a$ & 48.05 Аа $a$ & $40.15 \mathrm{Ca} a$ \\
\hline
\end{tabular}

$\mathrm{CV}(\%)$ 14.50

RS- Red Screen; CS- Chromatinet ${ }^{\oplus}$ Screen; BS- Black Screen and FS- Full Sun. Averages followed by different letters, upper case in columns, differ between cultivars; lowercase in lines, between environments; and italics, between the production times for the same cultivar and the same environments, by the Scott \& Knott test, at $5 \%$ probability. 
The greater accumulation of fresh matter by plants is related to the capacity of each cultivar to use edaphoclimatic factors more efficiently.

For cultivation in period of high temperatures, from September to December, the shaded environments provided higher production for the evaluated cultivars,

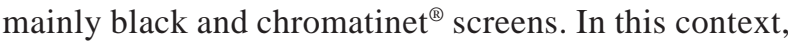
the $\mathrm{cv}$. Balsam under chromatinet ${ }^{\circledR}$ fabric, with about 66.0 t.ha ${ }^{-1}$. The best performance of the cultivars in these environments may be associated with the decrease in temperature and direct solar radiation caused by shading screens. Brzezinski et al. (2017), evaluating the Crisphead lettuce production also observed a better performance for plants conducted in protected environment, reinforcing that this type of technique provides a favorable microclimate, modifying temperature and relative humidity of the air, solar radiation and wind speed, influencing in a positive way the development and growth of the culture.

Regarding production times, a significant difference was observed for cultivars produced in full sun. The cvs. Irene, Balsamo and Rafaela doubled total production in the period from June to August/2018, when compared to September to December/2017. This difference can be justified with the data of average temperature and solar radiation (Figures 1 and 2), a reduction of $5{ }^{\circ} \mathrm{C}$ from September to December/2017 for June to August/2018.

For commercial productivity (Table 3), which refers to the total production of "heads" per hectare, a significant effect was observed for cultivars, environments and production times, such as, interaction among these factors. The cv. Balsamo emerges as the most productive in the season from June to August in full sun and chromatinet ${ }^{\circledR}$ fabric environments with 42.73 and 39.50 t.ha $^{-1}$, respectively. Moreover, there was no significant effect for this cultivar under chromatinet ${ }^{\circledR}$ fabric at the time of production, reaching 33.60 t.ha $^{-1}$. Therefore, the use of shading screen allows higher productivity in months of high temperature as well as in mild periods.

Crisphead lettuce reaches its full development in temperature range of $21.1^{\circ} \mathrm{C}$ to $26.6^{\circ} \mathrm{C}$ (Yuri et al., 2002). Using this reference that recommends the optimal cultivation condition, only the period from June to August had an average air temperature of $25^{\circ} \mathrm{C}$, whereas for September to December, this was $30^{\circ} \mathrm{C}$. As for the global radiation, lower values were observed for protected environments in both experiments, so the lower radiation promotes production of larger leaves, increasing the plant's fresh matter (Kosma et al., 2013). This fact was observed mainly in the period from September to December/2017, where the highest productivities were found in a protected environment.

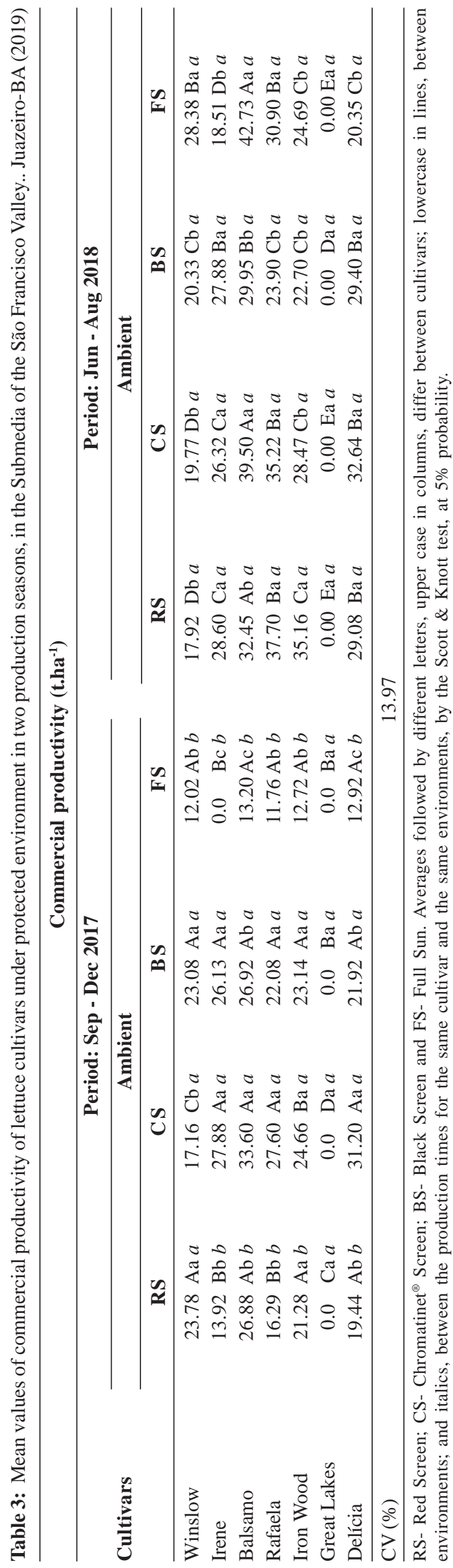

Rev. Ceres, Viçosa, v. 67, n.4, p. 263-271, jul/aug, 2020 
As for the production times, there was a $100 \%$ increase in the productivity of cultivars conducted in full sun, from June to August/2018, when compared to the period from September to December/2017.

Blind et al. (2014), studying the performance of Crisphead lettuce cultivars in the dry season of central Amazonia, found productivity varying from 11.0 to 23.0 t.ha ${ }^{-1}$. The cultivars: Delicia $\left(20.7 \mathrm{t} \mathrm{ha}^{-1}\right)$, Balsamo (21.2 t ha $^{-1}$ ), Irene (18.3 t.ha-1), Winslow (22.9 t ha-1), Great Lakes (18.7 t.ha $\left.{ }^{-1}\right)$, Rafaela (11.13 t ha $\left.{ }^{-1}\right)$, Iron Wood (22.5 t.ha-1), obtained lower yields than the present research under full sun conditions. This demonstrates the suitability of the Submedia region of the São Francisco Valley for production of Crisphead lettuce, since the chosen cultivar is appropriate to the region's conditions, so that it is competitive with the traditional production centers.

The higher cultivars productivities, in full sun, when compared to protected environment, in second cycle (June to August/2018), may be justified by excessive reduction of solar radiation, mainly in black screen, therefore, there was a limitation of energy radiant for culture. Paula et al. (2015), who report that dry matter production and lettuce productivity reached higher values in full sun when compared to shade, in the dry season in Acre. Ferreira et al. (2014) also observed higher dry matter production in dry season than in rainy season in Acre. Both authors justify that conditions of lower air temperature contributed to better performance of lettuce, since this plant originates in Mediterranean region and is better adapted to the mild temperature condition.

The early tillage in lettuce is related to high temperatures, and in tropical regions, mainly in the semiarid, where is located the Submedia of the São Francisco Valley, the high temperature is a preponderant factor due to its predominance during the year, playing great influence on productivity of Crisphead lettuce.

According to EMBRAPA's climatic data (2018), the average temperature in June, July and August was less than $25^{\circ} \mathrm{C}$ in the last five years, while the other nine months of the year exceeded $28^{\circ} \mathrm{C}$. Therefore, the use of shading screens can not be ruled out for Crisphead lettuce cultivation in the Submedia region of the São Francisco Valley, especially in second half of the year.

The chromatinet ${ }^{\circledR}$ and black screens were efficient in improving microclimatic conditions for Crisphead lettuce cultivation in the two production seasons, mainly during the period of high temperatures and consequently the higher evaporative demand. As the lettuce is not demanding high solar radiation and temperature, the use of shading screens promoted a reduction in the deleterious effects of these factors for the crop.

In the period from June to August/2018, where solar radiation and temperature were lower, the cultivars under chromatinet $^{\circledR}$ screen had better productivity than those developed under black screen. Thermo-reflective screens are more effective in reducing air temperature and these meshes provide $15 \%$ diffuse radiation to the environment. Because of this radiation behavior, it is suggested that this type of coverage is more effective in periods of mild temperatures, when compared with the others.

\section{CONCLUSIONS}

The cultivation in protected environment provides higher productivity of Crisphead lettuce from September to December, at that time the cultivars Balsamo and Delicia were highlighted under chromatinet ${ }^{\circledR}$ sreen. In the period from June to August there is no need to use screens, and cultivation in the full sun under the conditions of the Submedia of the São Francisco Valley, may be recommended.

The cultivar Balsamo was suitable for cultivation in the Submedia of the São Francisco Valley, in the first half of the year, cultivated in full sun.

\section{REFERENCES}

Aquino CF, Silva HP, Neves JMG, Costa CA, Aquino FF \& Costa CPM (2017) Desempenho de cultivares de alface sob cultivo hidropônico nas condições do norte de Minas Gerais. Revista Brasileira de Agricultura Irrigada, 11:1382-1388.

Blind AD \& Silva Filho DF (2015) Desempenho produtivo de cultivares de alface americana na estação seca da Amazônia Central. Bioscience Journal, 31:405-411.

Brzezinski CR, Geller A, Abati J, Werner F \& Zucareli C (2017) Produção de cultivares de alface americana sob dois sistemas de cultivo. Revista Ceres, 64:83-89.

CEAGESP-Companhia de Entrepostos e Armazéns Gerais de São Paulo (2018) Produtos CEAGESP. Available at: https:// www.ceagesp.gov.br/produtos/alface-Americana/. Accessed on: January $10^{\text {th }}, 2019$.

CONAB-Companhia Nacional de Abastecimento (2018) Boletim Hortigranjeiro Março 2018. Available at: https:// www.conab.gov.br/info-agro/hortigranjeiros-prohort/boletimhortigranjeiro. Accessed on: January 20 2019.

Embrapa - Empresa Brasileira de Pesquisa Agropecuária (2018) Dados meteorológicos. Available at: www.cpatsa.embrapa.br:8080/index.php?op=dadosmet. Accessed on: December $18^{\text {th }}, 2018$

Ferreira RLF, Alves ASSC, Araújo N, Kusdra JF \& Rezende MIFL (2014) Organic production of lettuce in different planting stations and tillage and mulching systems of soil. Bioscience Journal, 30:1017-1023

Gama DRDS, Mesquita AC, Yuri JE, Ferreira KM \& Souza V (2017) Different shading environments impact growth and yield of three mini-tomato cultivars. Revista Caatinga, 30:324-334.

Jie H \& Kong LS (1998) Growth and photosynthetic responses of three aeroponically grown Lettuce cultivars (Lactuca sativa L.) to different rootzone temperatures and growth irradiances under tropical aerial conditions. The Journal of Horticultural Science and Biotechnology, 73:173-180.

HFBrasil (2019) Anuário 2018-2019. Available at: https:// www.hfbrasil.org.br/br/revista/acessar/completo/anuario-20182019.aspx. Accessed on: January 20 2019. 
Hassanien RHE \& Ming L (2017) Influences of greenhouseintegrated semi-transparent photovoltaics on microclimate and lettuce growth. International Journal of Agricultural and Biological Engineering, 10:11-22.

Heriberto ACT (2010) Informações Agrometeorológicas do Polo Petrolina, PE/Juazeiro, BA - 1963 a 2009. Petrolina, EmbrapaSemiárido. 21p. (Documento, 233).

Iliæ SZ, Milenkoviæ L, Dimitrijeviæ A, Stanojeviæ L, Cvetkoviæ D, Kevrešan • \& Mastiloviæ J (2017) Light modification by color nets improve quality of lettuce from summer production. Scientia horticulturae, 226:389-397.

Iliæ SZ, Milenkoviæ L, Šuniæ L, Baraæ S, Cvetkoviæ D, Stanojeviæ L, Kevrešan Z \& Mastiloviæ J (2019) Bioactive constituents of red and green lettuce grown under colour shade nets. Emirates Journal of Food and Agriculture, 31:937-944.

Kosma C, Triantafyllidis V, Papasavvas A, Salahas G \& Patakas A (2013) Yield and nutritional quality of greenhouse lettuce as affected by shading and cultivation season. Emirates Journal of Food and Agriculture, 25:974-979.

Neves JFNF, Nodari IDE, Júnior SS, Dias LDE, Silva LB \& Dallacort R (2016) Produção de cultivares de alface americana sob diferentes ambientes em condições tropicais. Revista Agro@mbiente On-line, 10:130-136.

Oliveira EC, Carvalho JDA, Almeida EF, Rezende FC, Santos BGD \& Mimura SN (2014) Evapotranspiration of rose cultivated in protected environment. Revista Brasileira de Engenharia Agrícola e Ambiental, 18:314-321.

Resende GM, Yuri JE, Carvalho JG, Souza RJ, Rodrigues Júnior JC \& Mota JH (2005) Resposta da alface Americana (Lactuca sativa L.) a doses e épocas de aplicação de cobre. Ciência Agrotecnologia, 29:1209-1214.
Santi A, Carvalho MA, Campos OR, Silva AF, Almeida JL \& Monteiro S (2010) Ação de material orgânico sobre a produção e características comerciais de cultivares de alface. Horticultura Brasileira, 28:87-90.

Santiago EJP, Oliveira GMD, Leitão MDMVB, Rocha RC \& Pereira AVA (2018) Yield characteristics of cherry tomato cultivated with and without shading screen at different irrigation levels. Pesquisa Agropecuária Tropical, 48:374-381.

Santos HG, Jacomine PKT, Anjos LHC, Oliveira VA, Lumbreras JF, Coelho MR \& Cunha T (2018) Sistema brasileiro de classificação de solos. Brasília, Embrapa. 353p.

Stagnari F, Galiene A \& Pisante M (2015) Shading and nitrogen management affect quality, safety and yield of greenhouse-grown leaf lettuce. Scientia Horticulturae, 192:70-79.

Paula EMNC, Ferreira RLF, Souza Ribeiro AMA, Neto SEA \& Kusdra JF (2015) Desempenho agronômico de alface orgânica influenciado pelo sombreamento, época de plantio e preparo do solo no Acre. Pesquisa Agropecuária Brasileira, 50:468-474.

Yuri JE, Resende GM, Costa ND \& Gomes AS (2017) Desempenho agronômico de genótipos de alface Americana no Submédio do Vale do São Francisco. Horticultura Brasileira, 35:292-297.

Yuri JE, Resende GM, Mota JH, Souza RJ \& Rodrigues Júnior JC (2004) Comportamento de cultivares e linhagens de alface Americana em Santana da Vargem (MG), nas condições de inverno. Horticultura Brasileira, 22:322-325.

Yuri JE, Souza RJ, Freitas SAC, Júnior JCR \& Mota JH (2002) Comportamento de cultivares de alface tipo americana em Boa Esperança. Horticultura Brasileira, 20:229-232. 